\title{
Desain karakter film animasi Raya and The Last Dragon dalam membangun politik identitas Asia Tenggara
}

\author{
Agni Saraswati, a, $1^{*}$, Kathryn Widhiyanti, ${ }^{\mathrm{b}, 2}$, Nindya Galuh Fatmawati, c,3 \\ abc Institut Seni Indonesia, Jalan Parangtritis Km 6, Yogyakarta 55001, Indonesia \\ ${ }^{1}$ memorabilia151@gmail.com; ${ }^{2}$ kathryn@isi.ac.id; ${ }^{3}$ nindyagaluhf@gmail.com \\ * Corresponding Author
}

\begin{tabular}{l}
\hline INFO ARTIKEL \\
\hline Sejarah Artikel: \\
Diterima: 30 Juli 2021 \\
Direvisi: 6 September 2021 \\
Disetujui: 14 September 2021 \\
Tersedia Daring: 31 Oktober \\
2021 \\
\hline
\end{tabular}

\section{ABSTRAK}

Raya and the Last Dragon merupakan salah satu film animasi dari Walt Disney Studio yang dirilis pada awal 2021. Film tersebut menceritakan petualangan tokoh bernama Raya di negeri Kumandra yang mencari naga untuk membasmi musuh dan menyelamatkan dunia. Dalam film tersebut terlihat elemen kuat warna, aset, latar belakang, nilai-nilai Kata Kunci: Asia Tenggara Desain karakter Film Animasi Politik identitas Raya and The Last Dragon kehidupan, kebiasaan, dan adat istiadat yang sangat dekat dengan kehidupan sehari-hari masyarakat di Asia Tenggara. Dilihat dari indikasi tersebut, maka terdapat politik identitas yang mencerminkan bangsa di wilayah Asia Tenggara. Penelitian ini bertujuan meneliti bagaimana politik identitas terbentuk dan mempengaruhi persepsi penonton dalam mengapresiasi kebudayaan Asia Tenggara. Metode penelitian menggunakan pendekatan kualitatif dan dianalisis menggunakan teori politik identitas. Hasil penelitian menyimpulkan bahwa politik identitas yang dibangun melalui penceritaan nilai kehidupan, desain aset, dan desain karakter tokoh film Raya and the Last Dragon telah berhasil membangun persepsi tentang Asia Tenggara, sebagai bangsa yang berkebudayaan dan berkarakter dengan nilai-nilai spiritualitas untuk hidup berdampingan dengan bangsa lain, makhluk hidup, dan alam semesta. Namun, ketiadaan pengisi suara yang berasal dari Asia Tenggara pada film yang pertama kali rilis menggunakan bahasa Inggris menyebabkan hilangnya unsur "rasa memiliki" bagi penonton. Film ini menjadi penanda penting dalam politik dagang Amerika di wilayah Asia, di mana peluncuran film terjadi di saat bersamaan dengan banyaknya tragedi Asian Hate di wilayah Amerika dan Eropa.

\section{ABSTRACT}

Keywords:

Animated Film

Character Design

Identity Politic

Raya and The Last Dragon

Southeast Asia
Raya and the Last Dragon is one of the Walt Disney Animation Studio films released in early 2021. The film tells the adventures of a character named Raya in the land of Kumandra who is looking for dragons to eradicate enemies and save the world. The film shows strong elements of color, background, assets, attributes, life values, habits, and customs which are very close to the daily lives of people in Southeast Asia. Based on these indications, there is an identity politics that reflects the nation in Southeast Asian region. This study aims to examine how identity politics is formed and influences the audience's perception of appreciating Southeast Asian culture. The research method uses a qualitative approach and analyzed using the theory of identity politics. Results of the study conclude that identity politics built through values of life, asset design, and character design for the film Raya and the Last Dragon has succeeded in building perceptions about Southeast Asia, as a cultured and characterized nation with spiritual values to coexist with other nations, living things, and the universe. However, the absence of an Asian voice actor in the film, which was first released in English, caused the audience to lose the element of a sense of belonging. This film became an important mark in American trade 
politics in the Southeast Asian region, where the film's release occurred at the same time as the many Asian Hate tragedies in American and Europe.

(c) 2021, Saraswati, Widhiyanti, \& Fatmawati

This is an open access article under CC-BY-SA license

How to Cite: Saraswati, A., Widhiyanti, K., \& Fatmawati, N. G. (2021). Desain karakter film animasi Raya and The Last Dragon dalam membangun politik identitas Asia Tenggara. Satwika : Kajian Ilmu Budaya dan Perubahan Sosial, 5(2), 254-267, https://doi.org/10.22219/satwika.v5i2.17938

\section{Pendahuluan}

Walt Disney Animation Studio merupakan studio film Amerika yang didirikan pada 1923 (Merskin, 2020). Studio ini merilis film Raya and the Last Dragon pada awal 2021. Meskipun tidak ada hubungan secara langsung, film ini turut mewarnai berbagai peristiwa penting dunia dalam beberapa tahun terakhir, seperti persaingan perdagangan antara Amerika dan Tiongkok yang memuncak pada 2017, pandemi Covid-19 pada akhir 2019, dan tragedi Asian Hate di Amerika dan Eropa pada 2021.

Pada kurun waktu 30 tahun terakhir, Tiongkok mengalami perkembangan ekonomi yang tinggi sekitar 10\% dengan kemampuan ekspor yang juga tinggi (Kristiadi, 2021). Perang dagang yang terjadi ternyata memberikan pengaruh pada rantai pasokan global, banyak perusahaan mengevaluasi dan memperbaiki proses bisnis yang dijalankan (Pujayanti, 2018). Munculnya pandemi Covid-19 di Wuhan, Provinsi Hubei pada Desember 2019, lalu menyebar ke seluruh dunia sehingga menjadi permasalahan bersama (Susilo et al., 2020). Hal tersebut memojokkan warga keturunan Asia sebagai pembawa virus Covid 19 (Pratama, 2021). Peristiwa lain juga mewarnai berita-berita internasional, seperti insiden kebencian terhadap Asia (Asian Hate). Pada awal pemerintahan Joseph Biden ada beberapa peristiwa penyerangan terhadap warga Amerika Serikat (AS) keturunan Asia, khususnya China dan membuat Amerika Serikat sebagai negara yang majemuk menjadi rusak
(Nainggolan, 2021). Terkait dengan maraknya kasus rasial dan gender di Eropa dan Amerika, film ini dianggap membawa angin segar dan harapan bagi penonton yang memimpikan perdamaian bagi dunia Barat dan Timur. Film ini juga terlihat sebagai upaya promosi industri Hollywood bagi penonton di wilayah Asia. Meskipun diketahui bersama bahwa industri film di Asia, khususnya Hong Kong dan Korea Selatan cukup bagus merambah pasar Eropa. Sinema Korea Selatan saat ini telah merajai Asia dan menjadi saingan sinema Hollywood (Thalib, 2018).

Contoh penelitian menarik mengenai identitas karakter dalam film animasi adalah Animation and the Star Body yang ditulis oleh Julie Lobalzo Wright. Penelitian ini secara kualitatif deskriptif mengkaji bagaimana citra dan karakter seorang aktor bernama Dwayne Johnson dalam film animasi Moana digambarkan dengan sangat mirip dengan karakter asli di dunia nyata. Dalam penelitiannya, ia mendapatkan temuan bahwa terdapat efek spesial yang memungkinkan karakter merepresentasikan realitas dan fantasi. Inilah yang disebut sebagai post human (Wright, 2019). Dalam pengembangkan karakter ini, pengaruh gender, identitas, dan pencitraan karakter akan sangat berperan pada hasil animasinya.

Penelitian berikutnya yaitu "Makna Identitas Budaya dan Konflik Antaretnis dalam Film "Crazy Rich Asians", mampu mengungkap identitas budaya Asia-Amerika (Arsi \& Sobur, 2019). Penelitian dengan objek yang sama berjudul "Representasi Orientalisme Asia Dalam Film Crazy Rich 
Asians (Am I Really Asian If I'm Not Chinese?)" oleh Jannah menganalisis struktur dari narasi Crazy Rich Asians dan melihat bagaimana representasi pandangan Barat terhadap Asia dalam sebuah film (Jannah, 2020). Kedua penelitian tersebut menganalisis objek film yang sama, secara kualitatif, dan menggunakan analisis semiotik.

Hasil penelitian Arsi Sobur (2019), menemukan bahwa arti identitas dan konflik budaya Asia-Amerika dijelaskan melalui struktur eksternal penceritaan. Melalui narasi film Crazy Rich Asians, identitas budaya Asia-Amerika dimaknai sebagai kelompok mikrokultur yang sering dipermasalahkan identitasnya. Pemahaman mengenai konflik antaretnis dapat dimaknai sebagai gap identitas yang bermula dari prasangka orang Asia tradisional terhadap ke-Asia-an orang Asia-Amerika. Melalui karakterisasi, identitas Asia-Amerika digambarkan memiliki nilai-nilai dominan yang mencerminkan kolektivisme, penyesuaian terhadap norma, pengendalian emosi diri, sebagaimana hal-hal tersebut sejalan dengan pandangan budaya Asia. Jannah dan Lestari (2020), menganalisis setiap bagian karakter Asia yang dimunculkan dalam film Crazy Rich Asians didominasi oleh etnis Tionghoa dengan ciri khas berkulit kuning, bermata sipit, menggunakan penutur Mandarin dan memunculkan properti khas Tionghoa serta penekan kode teknis lainnya. Kedua, pada level ideologi yaitu matriarki, orientalisme, ras, serta kelas yang juga dibahas melalui film Crazy Rich Asians. Melalui pembahasan analisis level representasi dan level realitas bahwa ideologi yang terdapat pada film ini melihat dari sisi orientalisme.

Penelitian keempat, yaitu Thalib (2018) berjudul "Isu-Isu Identitas Budaya Nasional Dalam Film "Tenggelamnya Kapal Van der Wijck”. Isu-isu kompleksitas identitas budaya nasional muncul dalam film tersebut. Terdapat perbedaan suku dan kelas sosial yang menjadi penyebab konflik yang muncul dalam film serta dalam konteks kehidupan masyarakat Indonesia (Thalib,
2019). Dalam film ini, ikatan primordial dan etnosentrisme dianggap menjadi penghambat multikulturalisme dalam konteks Indonesia.

Keempat penelitian di atas memiliki kemiripan dengan penelitian ini. Penelitian mengenai Crazy Rich Asians sama-sama meneliti identitas ke-Asia-an dari perspektif Barat, dengan objek kajian berupa film. Penelitian mengenai Moana sama-sama mengupas pentingnya latar belakang pengisi suara dalam membentuk identitas karakter sebuah film animasi. Penelitian Thalib agak berbeda dengan penelitian penulis, namun kemiripannya adalah sama-sama mengupas identitas budaya dalam sebuah film. Beberapa contoh penelitian di atas menunjukkan bahwa belum ada penelitian ilmiah yang secara khusus mengupas identitas ke-Asia-an dalam film animasi Raya and The Last Dragon.

Film Raya and the Last Dragon menceritakan petualangan seorang tokoh bernama Raya di negeri Kumandra yang sedang mencari naga untuk membasmi musuh dan menyelamatkan dunia. Dalam film ini, unsur warna, aset latar belakang, atribut, arsitektur bangunan, makanan, nilainilai kehidupan, kebiasaan, dan adat istiadat sangat dekat dengan kehidupan sehari-hari masyarakat di Asia Tenggara, khususnya Indonesia. Dilihat dari indikasi tersebut, peneliti berpendapat bahwa ada politik identitas yang mencerminkan bangsa di Asia Tenggara melalui perspektif Barat.

Penelitian ini bertujuan untuk meneliti bagaimana politik identitas terbentuk dan mempengaruhi persepsi penonton dalam mengapresiasi budaya Asia Tenggara. Penulis menganilis adegan-adegan film Raya and The Last Dragon menggunakan teori identitas oleh Jane Batkin. Plot film tersebut adalah petualangan tokoh bernama Raya di negeri Kumandra, di mana dulunya manusia hidup berdampingan dengan para naga dengan damai. Sebuah insiden terjadi hingga menyebabkan pertikaian dan perpecahan para warga, serta bangkitnya para monster sehingga mengubah manusia menjadi batu. Petualangan pun dimulai. Raya mencari 
naga terakhir agar bisa membantunya menyatukan kembali warga Kumandra yang terpecah belah dan menghidupkan kembali manusia yang menjadi batu tersebut.

Kebaruan dari penelitian ini adalah sebagai berikut. Pertama, hanya sedikit film animasi yang menceritakan kisah Asia yang dibuat oleh Walt Disney. Seperti diketahui bahwa hanya Mulan yang dipublikasikan pada 1998, mengisahkan tentang kisah kepahlawanan dari Tiongkok, Asia. Sedangkan film Animasi Disney lain didominasi oleh kisah dari Eropa dan Amerika. Hal ini memperlihatkan bahwa film ini merupakan satu-satunya film mengenai Asia, khususnya Asia Tenggara, yang dibuat oleh Walt Disney. Kemudian pada 2021 muncul Raya and The Last Dragon. Kedua, penelitian ilmiah tentang politik identitas Raya and the Last Dragon belum terekspos secara mendalam. Sejauh ini, terdapat beberapa penelitian menarik mengenai identitas dalam film, namun tidak secara spesifik mengenai film animasi tersebut. Kedua alasan tersebut mendasari pentingnya penelitian untuk dilakukan dan mendasari unsur kebaruan dalam penelitian ini sehingga layak menjadi referensi bagi penelitian berikutnya.

Kontribusi penelitian ini adalah penambahan referensi mengenai kajian film Asia bagi studi ilmiah. Penelitian ini menjadi jawaban atas kurangnya penelitian yang dilakukan oleh peneliti Asia mengenai identitas budayanya sendiri.

\section{Metode}

Metode kualitatif dipilih dalam penelitian ini. Penelitian kualitatif merupakan suatu strategi inquiry yang menekankan pada pencarian makna, pengertian, konsep, karakteristik, gejala, simbol, maupun deskripis tentang suatu fenomena; fokus multimetode, bersifat alami dan holistik, mengutamakan kualitas, menggunakan beberapa cara dan disajikan secara naratif (Yusuf, 2019).

Tahapan penelitian kualitatif yang dilakukan peneliti sebagai berikut. Pertama, pemilihan data dimulai dengan memilih sampel objek. Dari sekian banyak objek film animasi, penelitian ini berfokus pada Raya and The Last Dragon sebagai pilihan objek yang tepat karena film ini baru dirilis, sehingga belum banyak diteliti. Kedua, film ini merupakan salah satu film animasi buatan Walt Disney yang bercerita mengenai Asia sehingga sesuai dengan topik permasalahan.

Kedua, presentasi data dimulai dengan mengidentifikasi elemen internal film yang mencakup pemilihan desain karakter, aset, latar belakang, dan adegan spesifik sebagai sampel. Hal ini dilakukan untuk mempermudah dan mempertajam analisis data. Beberapa poin yang menjadi elemen penentu dalam pemilihan sampel adalah salah satu adegan di awal, tengah, dan ujung yang mencerminkan nilai-nilai karakter dalam sikap mereka terhadap orang lain dan lingkungan. Penulis melakukan pengamatan dengan menonton film dan mengamati bagian yang dianggap mampu menyajikan ide tersebut. Peneliti mengkaji beberapa potongan adegan penting sebagai sampel penelitian yang dianggap mampu menunjukkan identitas yang ingin diungkapkan dalam film. Pada tahap ini, penulis memilih adegan:

1) Raya memasuki tempat suci untuk mencapai spirit Sisu di lingkaran Permata Naga. Raya melepas sepatunya sebelum memasuki kuil, pada menit ke 00:04:58 - 00:05:08.

2) Raya dan Ketua Benja mengundang berbagai suku untuk makan bersama dan mencoba untuk menyatukan semua bangsa untuk hidup damai di alam semesta pada menit ke 00:10:22 dan 00:11:24.

3) Desain karakter Raya dan Naga Sisu pada menit ke 01:30:25.

4) Aset desain berupa keris yang dipakai Ketua Benja melawan musuhnya pada menit ke 00:17:07.

5) Aset desain berupa tampah dan beras pada menit ke 0:08:19.

6) Aset desain berupa kain yang dibatik menggunakan canting pada menit ke 0:08:20. 
7) Aset desain berupa wayang pada menit ke 01:11:31.

8) Latar belakang berupa hamparan sawah menjadi lanskap yang sangat Asia pada menit ke 01:31:50.

Langkah ketiga, yaitu verifikasi data. Pada titik ini, kesimpulannya berasal dari kesesuaian analisis, teori, dan pengalaman empiris penonton yang diwakili oleh penulis. Penulis akan menonton film Raya and The Last Dragon dan menganilis adegan-adegan yang telah dipilih menggunakan teori identitas oleh Jane Batkin dalam bukunya berjudul Identity in Animation: A Journey into Self, Difference, Culture and the Body pada 2017.

\section{Hasil dan Pembahasan}

Politik identitas adalah sebuah alat politik suatu kelompok seperti etnis, suku, budaya, agama atau yang lainnya untuk tujuan tertentu, misalnya sebagai bentuk perlawanan atau sebagai alat untuk menunjukkan jati diri suatu kelompok (Soenjoto, 2019). Namun, konflik identitas dapat muncul jika seseorang memiliki banyak identitas berbeda yang saling bersaing dan terkadang saling bertentangan. Saat itu terjadi, maka akan terjadi kondisi di mana seseorang lebih tenggelam dalam budaya yang satu dan tidak familiar dengan budaya satunya (Fishman, 1999).

Pembuatan film animasi tidak lepas dari pentingnya membuat kemiripan antara citra dan karakter dengan animasi yang dibuat. Peneliti mengkaji beberapa potongan adegan dalam film untuk membedah serangkaian elemen dalam film. Secara rinci, penulis mengelompokkan objek pembahasan yang menunjukkan politik identitas sesuai kategori 1) nilai kehidupan yang terlihat pada kebiasaan, norma dan nilai etika masyarakat, 2) desain karakter tokoh utama, 3) aset desain berupa alat perlengkapan, senjata, dan bentuk kesenian, dan 4) latar belakang.

\subsection{Nilai Kehidupan dalam Film}

Salah satu adegan di awal film yang menunjukkan kebiasaan masyarakat dan kehidupan sehari-hari di Asia yaitu adegan terjadi saat Raya memasuki tempat suci untuk mencapai spirit Sisu di lingkaran Permata Naga. Raya melepas sepatunya sebelum memasuki kuil, seperti yang terlihat pada gambar 1 dan gambar 2.

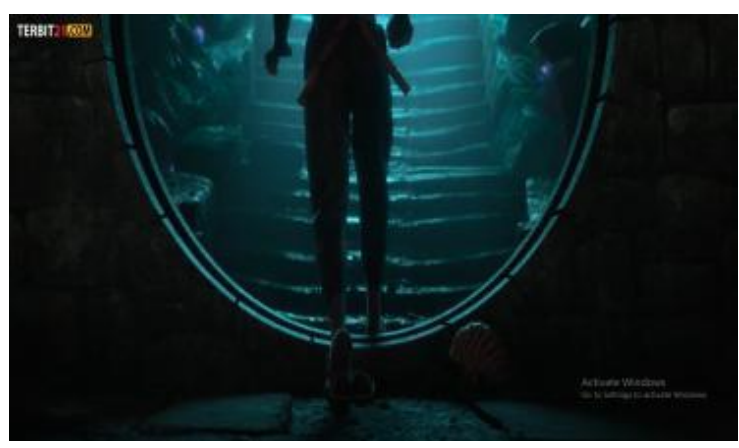

Gambar 1. Adegan dalam menit: 00:04:58 Raya melepas sepatunya (Sumber: Film Raya and The Last Dragon)

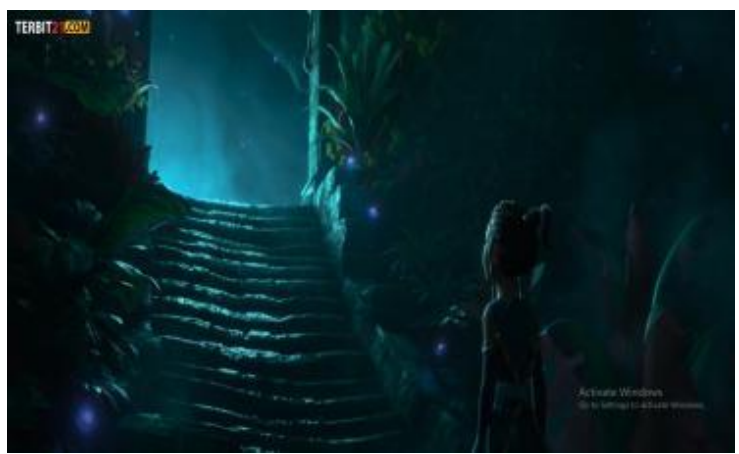

Gambar 2. Adegan dalam menit: 00:05:08 Raya melepas sepatunya (Sumber: Film Raya and The

Last Dragon)

Kebiasaan ini memperkuat identitas Asia yang percaya pada spiritualitas. Orangorang akan melepas sepatu atau sandal mereka ketika mereka memasuki tempat suci, bahkan beberapa daerah melakukan ini sebelum memasuki rumah mereka. Di Indonesia, masyarakat di Jawa, Sumatera, dan Bali mempraktikkan hal yang sama. Sebagai contoh, di sebuah situs budaya $\mathrm{Ki}$ Buyut Trusmi Cirebon di Indonesia mewajibkan pengunjung untuk melepas alas kaki saat akan masuk ke dalam kompleks situs serta mencuci kakinya dengan air. Melepas alas kaki dan mencuci kaki dengan air merupakan Langkah untuk menyucikan diri dikarenakan ada ruang atau area yang akan dilewati merupakan area yang lebih suci (Mujabuddawat, 2016). Praktik ini 
sepertinya muncul sejak pengaruh Islam masuk ke Asia. Umat muslim melakukan ibadah dengan cara shalat ke masjid. Dalam kitab suci Al-Qur'an, mereka diajarkan untuk melepaskan sepatu sebelum masuk ke dalam masjid, dan bahkan mereka harus berwudhu terlebih dahulu.

Adegan dalam film ini memperkuat gagasan Jane Batkin yang menegaskan bahwa politik identitas adalah sesuatu yang melekatkan dirinya pada budaya dan kebangsaan, pada tempat dan masa lalu, pada diri sendiri dan orang lain (Batkin, 2017). Pandangan ini menyebutkan bahwa karakter terbentuk melalui proses identitas yang dibagikan, di mana ia melekat pada kebudayaan, rasa kebangsaan terhadap tempat tinggal dan masa lalu. Raya menunjukkan bahwa identitasnya dipengaruhi adanya praktik norma dan etika kesopanan yang melekat erat dalam masyarakat.

Adegan lain, ditunjukkan pada gambar $\underline{3}$ dan gambar 4 terlihat bahwa Raya dan ayahnya mencoba menyelamatkan dunia dan menyatukan semua bangsa untuk hidup damai di alam semesta. Ayahnya percaya bahwa mereka dahulu adalah satu bangsa yang hidup secara harmonis. Semangat persatuan ini pun diwariskan pada Raya.

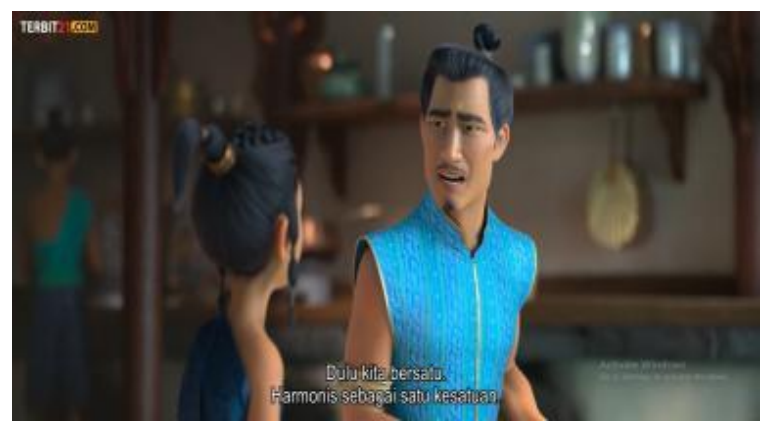

Gambar 3. Adegan dalam menit: 00:10:22 menunjukkan bahwa Raya dan ayahnya mencoba untuk menyatukan semua bangsa. (Sumber: Film Raya and The Last Dragon)

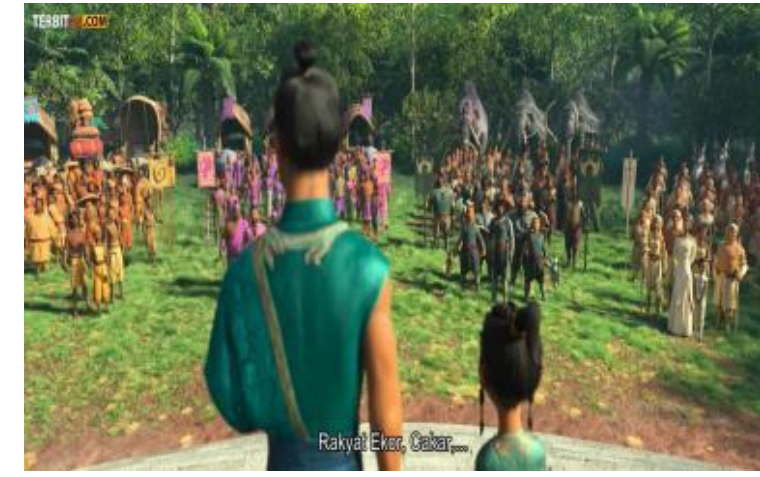

Gambar 4. Adegan dalam menit: 00:11:24 menunjukkan bahwa Raya dan ayahnya mencoba untuk menyatukan semua bangsa (Sumber: Film Raya and The Last Dragon)

Ini adalah ide utama dari seluruh cerita. Ini bisa menjadi adegan penting yang menunjukkan bagaimana karakter utama mulai menangani masalah dan menemukan solusi. Hal ini sesuai dengan gagasan mengenai penceritaan sebagai elemen penting dalam film. Menurut Francis Glebas cerita adalah serangkaian peristiwa tentang karakter yang menginginkan sesuatu. Cerita membangun sebuah krisis sampai karakter tidak mendapatkan apa yang dia inginkan, melainkan apa yang ia butuhkan. Cerita hebat memiliki karakter dengan konflik internal yang diselesaikan sebagai konflik eksternal (Glebas, 2009). Ide utama cerita Raya ini didukung bagaimana tokoh Raya tampak memiliki hubungan erat dengan keluarga dan sangat menghormati ayahnya. Hal ini ditunjukkan ketika dia membantu ayahnya untuk menyatukan semua bangsa tetapi dikhianati oleh rakyat. Dia berusaha keras untuk menemukan cara untuk menyelamatkan ayahnya dan orang-orang yang berubah menjadi batu. Semangat persatuan ini sangat dekat dengan ideologi bangsa Indonesia yaitu Pancasila di mana moto Bhineka Tunggal Ika menjadi semangat pemersatu bangsa. Bhinneka Tunggal Ika sangat bermakna bagi Indonesia yang memiliki berbagai macam kebudayaan (Arsitowati, 2017). Gagasan ini sesuai dengan penjelasan Batkin bahwa politik identitas, mengacu pada penyatuan karakter yang memiliki unsur identitas bersama, serta masyarakat yang terpinggirkan karena "perbedaan" mereka (Batkin, 2017). 
Persatuan dalam keberagaman telah menjadi ideologi terpenting yang dideklarasikan oleh para pendiri bangsa Indonesia. Semangat ini juga diprakarsai oleh patih Gadjah Mada, dari kerajaan Majapahit, yang mencetuskan sumpah Palapa untuk menyatukan kepulauan nusantara. Bhineka Tunggal Ika menunjukkan upaya penyadaran untuk melihara kemajemukan sebagai aset pemersatu bangsa yang telah terpecah belah oleh konflik sosial (Marta \& Rieuwpassa, 2018).

\subsection{Desain Karakter Raya dan Naga Sisu}

Karakter dalam sebuah film menjadi elemen utama yang sangat berpengaruh terhadap cerita dari film animasi (Yulianti, 2021). Desain karakter yang baik akan memberikan gambaran kepada audiens mengenai tokoh-tokoh yang ada dalam sebuah film animasi (Mutiarasani \& Sidhartani, 2018). Karakter yang dirancang diharapkan dapat menggambarkan kepripadian dan sifat-sifat dari yang dimiliki (Fathoni et al., 2018).

Karakter yang diamati peneliti yaitu Raya dan Naga Sisu sebagai karakter utama dalam film Raya and The Last Dragon.

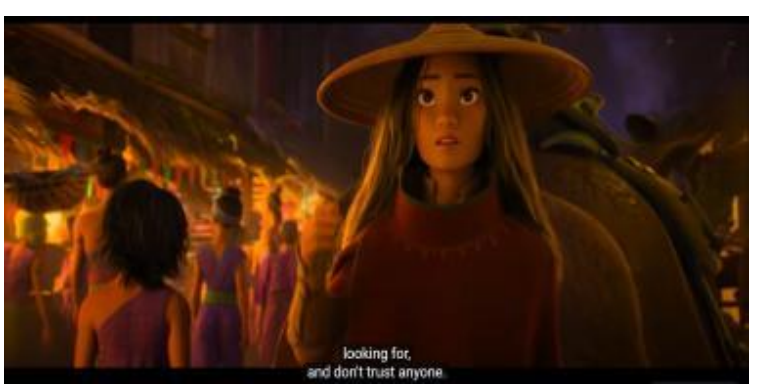

Gambar 5. Karakter Raya.(Sumber: Film Raya and The Last Dragon)

Raya merupakan karakter utama, gambar 5, yang sangat identik dengan wanita Asia Tenggara dengan warna kulit sawo matang, mata besar serta rambut hitam dan tebal. Asia Tenggara merupakan daerah beriklim tropis, sehingga membuat masyarakatnya tepapar sinar matahari langsung dalam kesehariannya (Arsitowati, 2017). Sebagai contoh warna kulit sawo matang merupakan warna kulit khas hampir sebagian penduduk Indonesia (Sukisman et al., 2021).

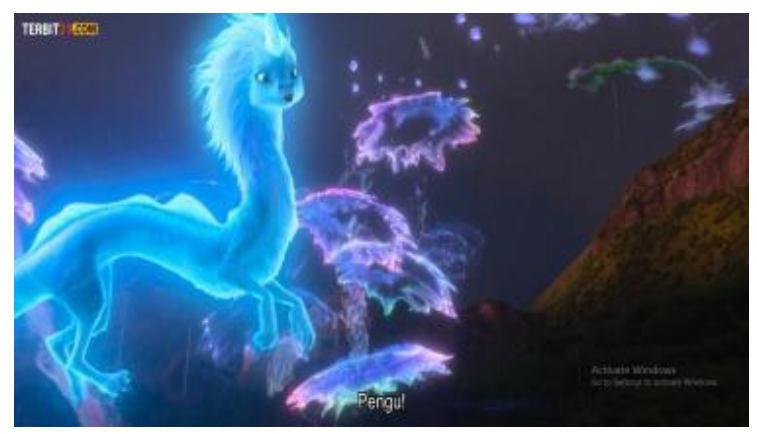

Gambar 6. Karakter Sisu di adegan dalam menit 01:30:25 (Sumber: Film Raya and The Last Dragon)

Sisu, gambar 6, merupakan nama naga terakhir yang menemani Raya untuk menyelamatkan Kumandra. Sisu merupakan naga dengan karakter khas Naga Asia yaitu memiliki 4 kaki, surai dan tanduk (gambar 9). Dalam budaya Timur, Naga menjadi lambang kebaikan dan keberuntungan (Suryana, 2018). Simbol Naga di Asia Tenggara juga memiliki makna yang sama yaitu kebaikan dan keberuntungan. Naga juga memiliki makna simbolis sebagai pelindung atau penjaga. Beberapa jenis Naga dianggap setengah Dewa yang menyangga bumi (Santiko, 2015). Berdasarkan makna-makna simbolis yang baik dari Naga, maka Naga banyak dijadikan sebagai ornamen-ornamen dalam kehidupan masyarakat. Gambaran Naga Asia dapat dilihat dari beberapa ornamen yang ada dalam benda-benda adat suatu daerah di Asia Tenggara. Sebagai contoh gambar 7 merupakan naga dari Nusa Tenggara Timur dari Indonesia yang terdapat dalam Lau Witikau. Naga digambarkan memiliki 4 kaki, surai dan tanduk. Pada gambar 8 juga menunjukkan gambaran naga Tiongkok yang memiliki 4 kaki, surai dan tanduk.

Di Asia Tenggara, selain menjadi ornamen benda budaya, naga juga banyak dibuat sebagai patung. Umumnya patung ini dipakai sebagai hiasan di tempat ibadah, seperti kuil dan Klentheng (gambar 10 \& 11) serta hiasan di depan istana raja. Di Yogyakarta, hiasan ini juga dapat ditemukan di depan rumah bangsawan Keraton. 


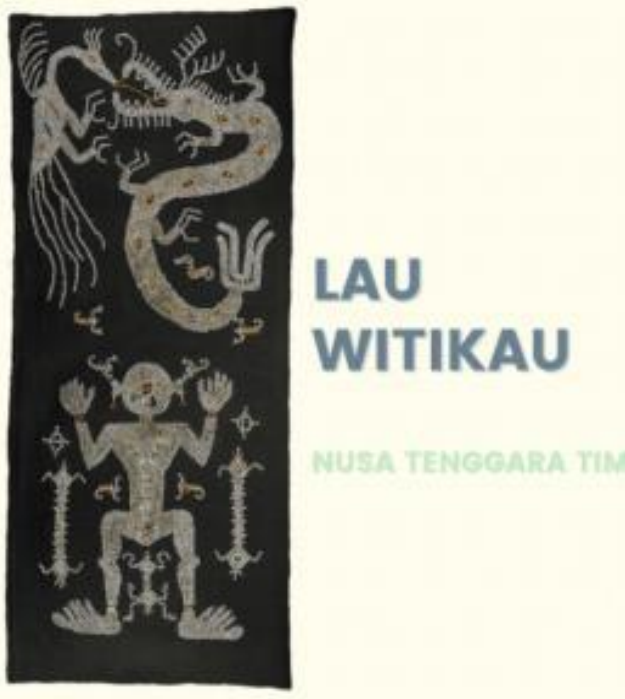

Gambar 7. Naga Asia dari Nusa Tenggara Timur Sumber: https://www.museumnasional.or.id/naganaga-di-museum-nasional-3834)

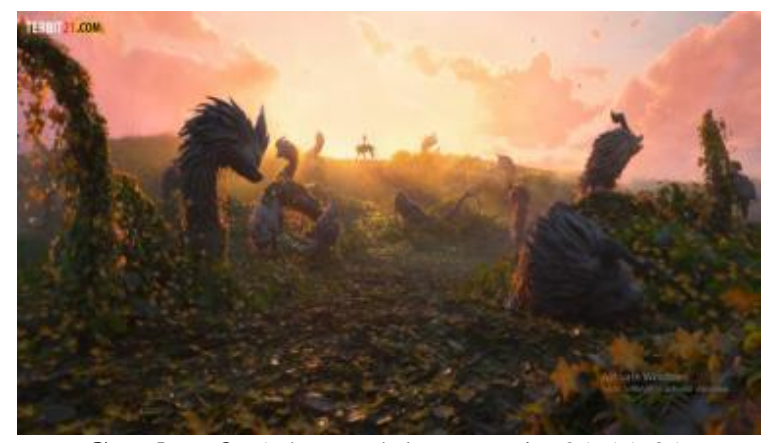

Gambar 9. Adegan dalam menit 01:11:31. (Sumber: Film Raya and The Last Dragon)

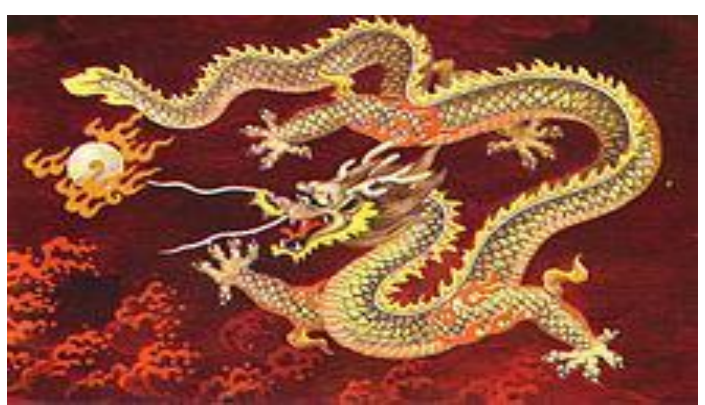

Gambar 8. Naga Tiongkok (Sumber : ttp://p2k.um-surabaya.ac.id/id3/3045-2942/Nagaina_129971_um-surabaya_p2k-um-surabaya.html)

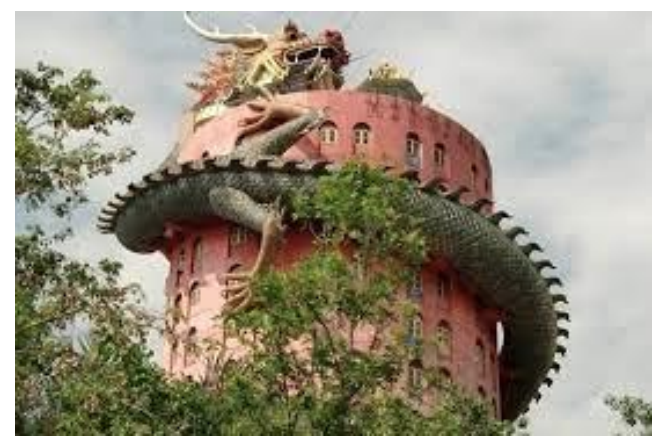

Gambar 10. Patung Naga di Kuil Naga Thailand

(Sumber: https://travel.detik.com/internationaldestination/d-2493500/kuil-di-thailand-ini-dililit-naga )

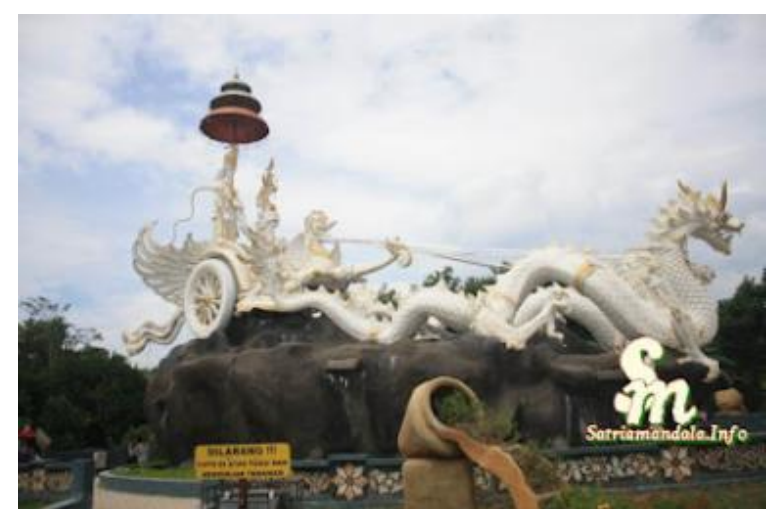

Gambar 11. Patung Tugu Rato Nago Besanding di Bali, Indonesia

(Sumber:https://www.bangyus.com/2017/02/patung-tugu-ratonago-besanding-di.html)

Penciptaan desain karakter Raya dan Sisu dibuat hidup dan menyerupai model aslinya. Hal ini sesuai dengan konsep animasi menurut Batkin, di mana ia menyebutkan bahwa animator memberi kehidupan pada animasi. Muncul dari keheningan, animasi memunculkan kehidupan dari kematian. Karakter memperoleh kesadaran diri yang terkait dengan kepribadian dan masyarakat, melalui tangan sang animator (Batkin, 2017). Kemiripan tersebut juga mempengaruhi 
pembentukan identitas, sebagaimana disampaikan Bryan Tillman bahwa arketipe mewakili kepribadian dan ciri-ciri karakter yang kita sebagai manusia identifikasi. Arketipe dianggap sebagai bentuk karakter cetakan asli atau model seseorang, sifat, atau perilaku yang ingin kita salin atau tiru. Cerita dan kepribadian akan memperkuat desain karakter secara sosiologis dan psikologis. Dalam pembuatan film, referensi dimulai melalui penelitian dan pengamatan sesuatu dari kehidupan untuk meyakinkan penonton bahwa desain yang dibuat sesuai dengan gambar visual asli (Tillman, 2011).

\subsection{Desain Aset berupa Senjata, Perlengkapan, dan Bentuk Kesenian}

Peneliti mengamati beberapa aset dalam Film Raya and The Last Dragon yang sangat menunjukkan identitas Asia Tenggara. Salah satunya adalah keris yang dipakai Ketua Benja melawan musuhnya (gambar 12). Keris merupakan jenis senjata berukuran pendek dan berbentuk unik dari kebangsaan melayu. Senjata tersebut telah digunakan sejak melebihi 600 tahun lalu. Keris telah berkembang di kawasan kependudukan Melayu, seperti Indonesia, Malaysia, Thailand, Singapura, Filipina, dan Brunai. Saat berperang, keris dipakai untuk pertahanan diri. Selain itu, ia merupakan alat kebesaran raja (Darmojo, 2019). Berdasarkan sumber dari situs UNESCO, keris telah diresmikan sebagai warisan budaya dunia pada 2008. Kris atau keris adalah sebuah belati asimetris khas dari Indonesia. Ia dipakai sebagai senjata dan juga benda spiritual. Keris dianggap memiliki kekuatan magis. Keris paling awal diketahui berasal dari abad ke-10 dan kemungkinan besar menyebar dari pulau Jawa ke seluruh Asia Tenggara (UNESCO, 2008). Sampai saat ini, keris masih menjadi benda yang dilestarikan dan digunakan dalam acara-acara tertentu. Bentuk keris bergelombang dan memiliki ukiran yang sangat khas.

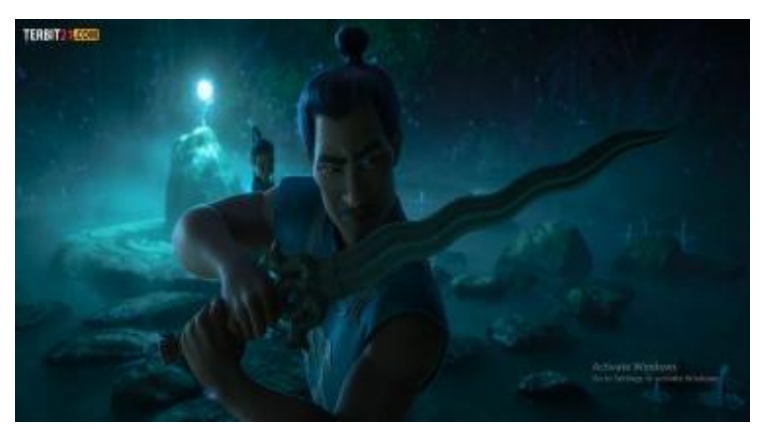

Gambar 12. Adegan dalam menit 00:17:07.

(Sumber: Film Raya and The Last Dragon)

Aset yang kedua adalah tampah dan beras, yang juga sangat identik dengan Asia Tenggara. Hampir seluruh negara di Asia Tenggara mengkonsumsi beras sebagai makanan pokok. Secara tradisional, beras dibersihkan dari kotoran dengan menggunakan tampah. Tampah terbuat dari bambu dan di setiap daerah memiliki bentuk yang khas, tetapi secara umum berbentuk bulat (gambar 14).

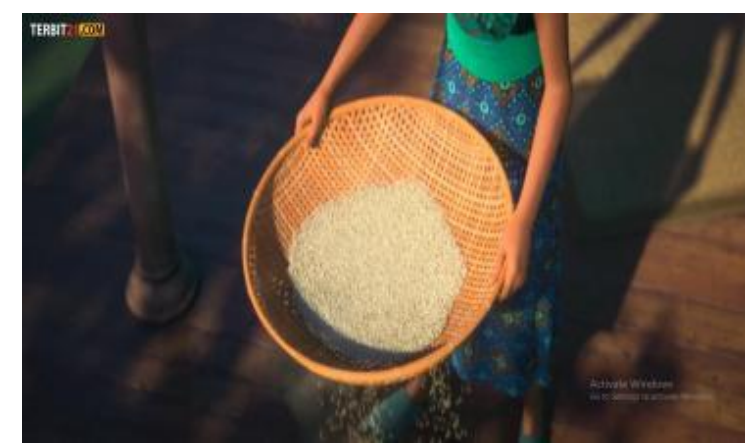

Gambar 13. Adegan dalam menit: 0:08:19. (Sumber: Film Raya and The Last Dragon)

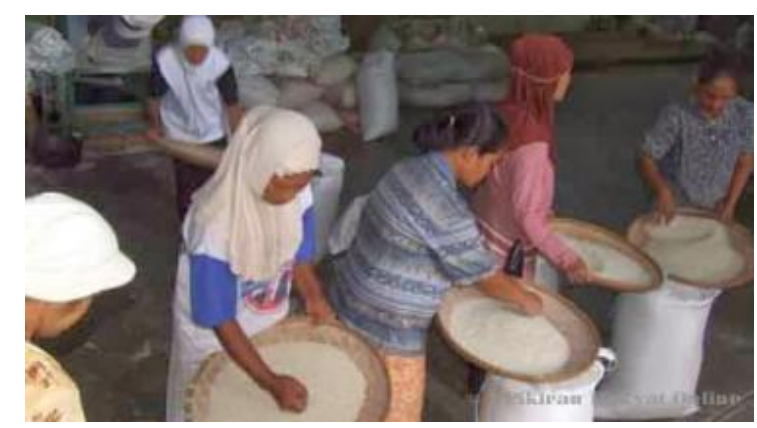

Gambar 14. Tampah dan Beras (Sumber: http://pkspadangok.blogspot.com/2014/02/ antara-beras-kotorannya-dan-pks.html)

Pada adegan di menit ke 00:08:19 (gambar 13), terdapat aset yaitu berupa kain yang dibatik menggunakan canting (gambar $\underline{15} \underline{\&} 16)$. Menurut UNESCO, batik menjadi 
identitas Indonesia dan telah diresmikan sebagai warisan budaya dunia pada tahun 2009 (Trixie, 2020).

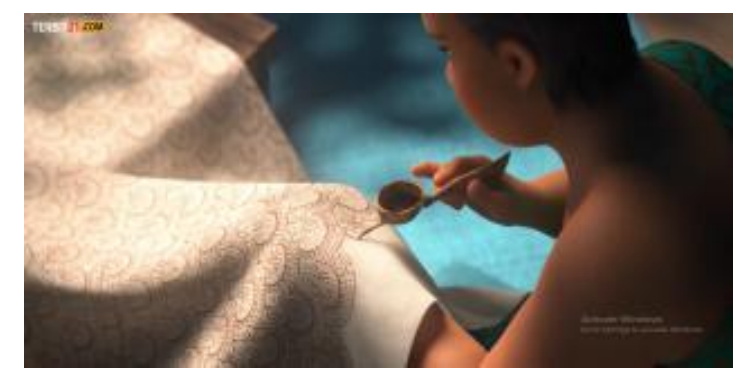

Gambar 15. Adegan dalam menit: 0:08:20. (Sumber: Film Raya and The Last Dragon)

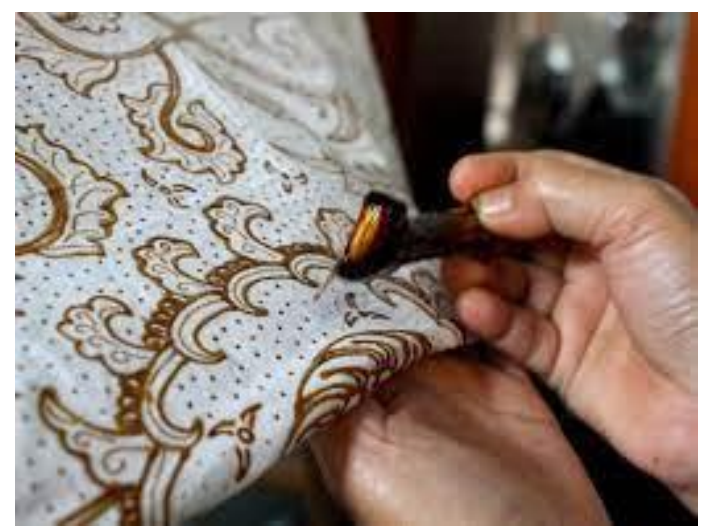

Gambar 16. Batik dan Canting

(Sumber:https://sayaajarkan.com/infofeed/2017/10/24/5-teknik-membuat-batik-yangumum-dipakai-91403/)

Asal muasal batik masih menjadi misteri. Berdasarkan bukti sejarah, pada tahun 1677 telah muncul perdagangan sutera dari Cina ke Jawa, Sumatra, Persia dan Hindustan. Hal tersebut pun didukung oleh adanya catatan tertulis tentang ekspor batik dari Jawa ke Malabar pada 1516 disusul tahun 1518 (Kustiyah, 2017).

Budaya bercerita menggunakan media layar dan bayang-bayang sangat indetik dengan pertunjukan wayang di beberapa Negara di Asia, seperti Thailand, Tiongkok, dan Indonesia. Pada gambar 17 yaitu adegan di menit ke 01:11:31 terlihat adegan dimana pemimpin suku Taring bercerita dan menyampaikan pendidikan kepada anakanak dengan menggunakan wayang (gambar 18). Hal tersebut memberikan identitas bahwa selain sebagai bagian dari budaya, wayang juga memiliki fungsi sebagai media edukasi masyarakat (Fathoni et al., 2018).

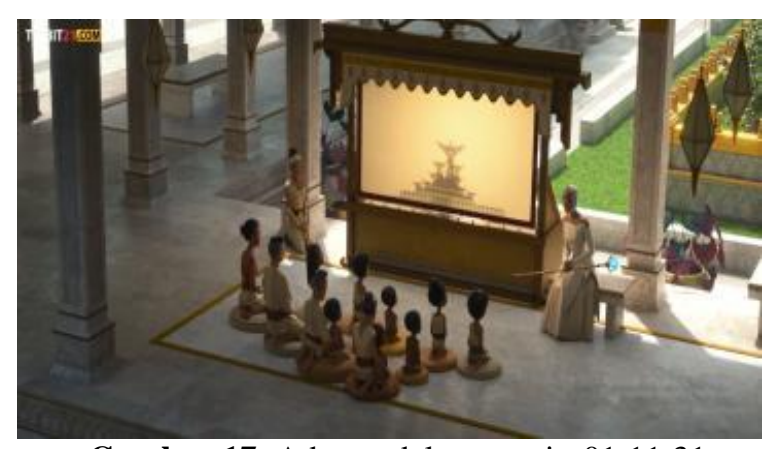

Gambar 17. Adegan dalam menit 01:11:31.

(Sumber: Film Raya and The Last Dragon)

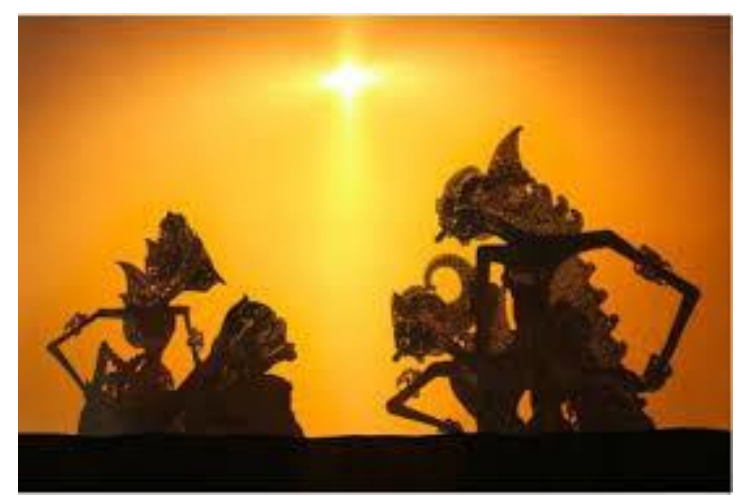

Gambar 18. Wayang (Sumber:

https://m.medcom.id/gaya/wisata/RkjlymVN-4-tipsbelanja-wayang-dan-batik-di-jawa-tengah)

Berdasarkan situs UNESCO (2008), wayang telah diresmikan sebagai warisan budaya dunia pada tahun 2008 yang berasal dari Jawa, Indonesia. Sebagaimana dalam situs tersebut dinyatakan bahwa bentuk cerita kuno wayang, yang terkenal akan wayangnya yang rumit dan gaya musiknya yang kompleks, berasal dari pulau Jawa di Indonesia. Selama sepuluh abad wayang berkembang di istana kerajaan Jawa dan Bali. Kebudayaan dan kesenian menjadi penguatan identitas komunitas. Sebagaimana komunitas kejawen di Jawa melestarikan ritual, tradisi, dan upacara perayaan desa dengan mengadakan pementasan wayang kulit (Hudayana, 2021).

\subsection{Latar Belakang Rumah dan Persawahan}

Pada adegan menit ke 01:31:50 terdapat visual hamparan sawah yang berterasering seperti di Bali (Narottama et al., 2017), dengan rumah tradisional yang sangat mirip 
dengan rumah sawah khas Sunda, Jawa Barat, Indonesia (gambar 19 \& 20).

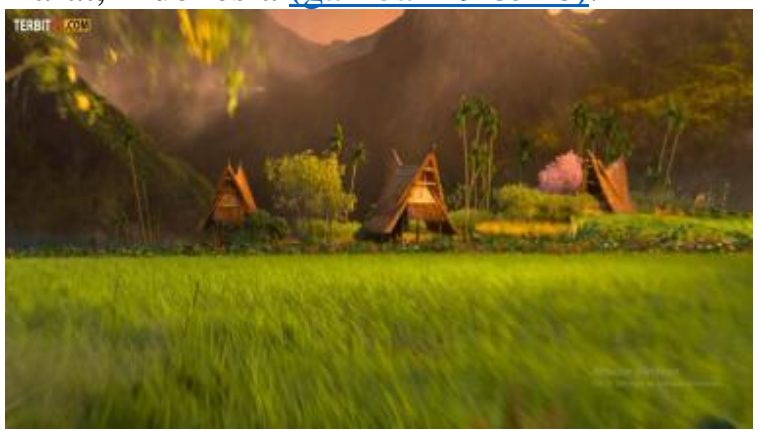

Gambar 19. Sawah, rumah, dan pegunungan pada adegan dalam menit 01:31:50 (Sumber: Film Raya and The Last Dragon)

Rumah sawah memiliki ciri dengan atap yang menggunakan jerami dan memiliki 2 bidang atap saja yang disebut bentuk jolopong (Sahril \& Satwikasar, 2019). Selain sawah, pegunungan juga menjadi khas wilayah tropis di Asia.

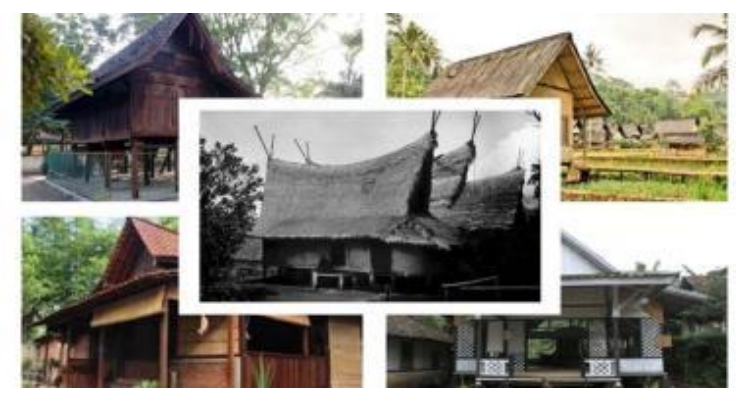

Gambar 20. Rumah adat Sunda, Jawa Barat, Indonesia (Sumber:

https://www.merdeka.com/jabar/8-jenis-rumah-adatsunda-yang-jarang-di-ketahui-salah-satunyamemperlancar-pertanian.html)

Berdasarkan temuan di atas, film ini terlihat menggabungkan budaya dari berbagai negara di Asia Tenggara menjadi satu wadah peleburan monolitik. Nilai nilai kehidupan, nilai spiritualitas, budaya membatik, melepas sepatu, wayang, dan senjata keris yang dekat dengan Indonesia. Perpaduan berbagai budaya terlihat dengan adanya identitas-identitas budaya di Asia Tenggara seperti Malaysia, Thailand, dan Indonesia. Hal ini terasa seperti nostalgia yang indah dan eksotis. Namun, cakupan budaya yang ditampilkan terlalu luas menjadi kelemahan karena rasa kepemilikan (sense of belonging) penonton juga akan tipis. Penonton hanya akan merasa akrab tetapi tidak merasa seperti mereka benarbenar memiliki atau tinggal di dalamnya. Hal ini juga didukung dengan tidak adanya pengisi suara dari Asia Tenggara, di mana aktor asal Asia Timur mendominasi film ini. Ini menunjukkan kurangnya kepercayaan Walt Disney pada aktor lokal Asia Tenggara. Seperti yang kita ketahui bahwa Asia Tenggara dan Asia Timur memiliki perbedaan dalam budaya mereka, terutama mengenai dialek dalam berbicara, meskipun kedua wilayah tersebut berada dalam satu benua. Dalam film animasi, dialek suara menjadi identitas penting yang dapat mendukung karakter seseorang dan dari mana dia berasal. Ketika aktor mengisi suara pada animasi, maka ia meminjamkan personanya untuk menghidupkan karakter tersebut melalui karakteristik, respons, dan emosi (Wright, 2019). Terlepas dari kekurangan tersebut, film ini menyuguhkan karakter, lanskap dan narasi budaya Asia Tenggara bagi penonton global. Poin yang menarik adalah film ini menempatkan posisi karakter wanita yang kuat secara fisik dan mental. Para wanita dalam film ini memainkan peran yang lebih dominan daripada karakter pria, tanpa harus mengorbankan sisi feminin mereka. Misalnya dalam kisah Mulan, di mana karakter wanita harus berpakaian seperti pria untuk membuktikan diri, tetapi para wanita Kumandra masih mengenakan pakaian dan perhiasan yang elegan sambil tetap menunjukkan potensi mereka. Raya and the Last Dragon tidak hanya menyentuh target feminis tetapi juga mampu mengubah pesan "kepercayaan pada persaudaraan" (trust on sisterhood). Niat Walt Disney dalam mengerjakan proyek Raya and the Last Dragon adalah untuk mendapatkan kepercayaan dari penonton Asia dalam hal mewujudkan budaya Asia sebagai budaya populer dari perspektif Barat. Pembuatan film tersebut tentu dilatarbelakangi sejumlah tujuan politis seperti promosi dagang Hollywood ke Indonesia. 


\section{Kesimpulan}

Hasil penelitian menyimpulkan bahwa politik identitas yang dibangun melalui nilai kehidupan, aset, latar belakang dan karakter tokoh film Raya and the Last Dragon cukup membangun persepsi tentang Asia Tenggara, sebagai bangsa yang berbudaya dan berkarakter dengan nilai-nilai spiritual untuk hidup berdampingan dengan bangsa lain, makhluk hidup, dan alam semesta. Namun, tidak adanya pengisi suara dari Asia Tenggara pada film tersebut saat rilis pertama kali, menyebabkan penonton kehilangan unsur memiliki. Film ini menjadi penanda penting bahwa negara Barat semakin gencar memperluas strategi dagangnya melalui industri film ke wilayah Asia Tenggara.

Implikasi dari hasil penelitian ini tentunya adalah penambahan referensi mengenai kajian film Asia bagi studi ilmiah. Kurangnya penelitian yang dilakukan oleh peneliti Asia mengenai identitas budayanya sendiri menjadi peluang bagus bagi penelitian berikutnya. Selama ini Asia selalu terpaku pada peneliti dari Barat yang dianggap lebih ahli mengenai Asia.

Saran penulis adalah, perlu lebih banyak lagi peneliti-peneliti Asia yang ahli dalam mengemukaan gagasan dan persepsi mengenai identitas dirinya untuk dikemukakan di wilayah global.

\section{Ucapan Terima Kasih}

Saya mengucapkan terima kasih kepada Tim Produksi Film Raya and The Last Dragon atas dedikasinya mengangkat identitas Asia Tenggara ke dalam film animasi.

\section{References (Daftar Pustaka)}

Arsi, M. A., \& Sobur, A. (2019). Makna Identitas Budaya Dan Konflik Antaretnis Dalam Film "Crazy Rich Asians." Mediator: Jurnal Komunikasi, 12(1), 4660.

https://doi.org/10.29313/mediator.v12i1. 4519

Arsitowati, W. H. (2017). Kecantikan Wanita
Korea Sebagai Konsep Kecantikan Ideal Dalam Iklan New Pond's White Beauty: What Our Brand Ambassadors Are Saying. HUMANIKA, 24(2), 84-97. https://ejournal.undip.ac.id/index.php/hu manika/article/view/17572/12952

Batkin, J. (2017). Identity in Animation: A Journey into Self, Difference, Culture and the Body. Routledge. https://bok.asia/book/5264519/146b82

Darmojo, K. W. (2019). Eksistensi Keris Jawa dalam Kajian Budaya. Texture, 2(1), 49$60 . \quad$ https://jurnal.isiska.ac.id/index.php/TXT/article/view/26 $30 / 2378$

Fathoni, A. F. C. A., Kartika, R., \& Lubis, S. H. (2018). Penerapan Physiognomy Karakter Pada Animasi. Dimensi DKV, 3(1), 31-42. https://www.trijurnal.lemlit.trisakti.ac.id /seni/article/view/2846/2484

Fishman, J. A. (1999). Handbook of Language and Ethnic Identity. Oxford University Press. https://bok.asia/book/837828/601a3f

Glebas, F. (2009). Directing the story: Professional storytelling and storyboarding techniques for live action and animation. Routledge

Hudayana, B. (2021). Pengembangan SeniBudaya sebagai Penguatan Identitas Komunitas Kejawen dan Santri di Desa pada Era Reformasi. Satwika: Kajian Ilmu Budaya Dan Perubahan Sosial, 5(1), 1-17. https://doi.org/10.22219/satwika.v5i1.15 641

Jannah, S. K. (2020). Representasi Orientalisme Asia dalam Film Crazy Rich Asians. 8 No.1. https://ejournal3.undip.ac.id/index.php/i nteraksi-online/article/view/26189

Kristiadi, R. (2021). Pengaruh Perang Dagang China - Amerika Serikat Terhadap Hubungan Dagang Indonesia Dengan 
Amerika Serikat. Jurnal Politico, 10(4), 16.

https://ejournal.unsrat.ac.id/index.php/p olitico/article/view/32460

Kustiyah, I. E. (2017). Batik Sebagai Identitas Kultural Bangsa Indonesia Di Era Globalisasi. Gema, 30(52), 2456-2472. https://media.neliti.com/media/publicati ons/62476-ID-batik-sebagai-identitaskultural-bangsa.pdf

Marta, R. F., \& Rieuwpassa, J. S. (2018). Identifikasi Nilai Kemajemukan Indonesia Sebagai Identitas Bangsa dalam Iklan Mixagrip Versi Keragaman Budaya. Jurnal Kajian Komunikasi, 6(1), 37.

https://doi.org/10.24198/jkk.v6i1.15416

Merskin, D. L. (2020). Walt Disney Company. The SAGE International Encyclopedia of Mass Media and Society, July. https://doi.org/10.4135/9781483375519. n726

Mujabuddawat, M. Al. (2016). Symbolism of Complex Buildings in The Site of $\mathrm{Ki}$ Buyut Trusmi Cirebon. 12(2), 175-190. https://media.neliti.com/media/publicati ons/144677-ID-simbolisme-kompleksbangunan-situs-ki-bu.pdf

Mutiarasani, D., \& Sidhartani, S. (2018). Perancangan Karakter Dyah Pitaloka pada Film Animasi Perang Bubat. Visual Heritage: Jurnal Kreasi Seni Dan Budaya, 1(01), 31-37. https://doi.org/10.30998/vh.v1i01.10

Nainggolan, P. P. (2021). 7 Meningkatnya Aksi-aksi Rasis Terhadap Warga Keturunan Asia di Amerika Serikat. Info Singkat: Bidang Hubungan Internasional, $\quad$ XIII(9), 7-12. http://berkas.dpr.go.id/puslit/files/info_si ngkat/Info Singkat-XIII-9-I-P3DI-Mei2021-160.pdf

Narottama, N., Arun, A. A. A., \& Arianty, S. (2017). Proses Pembentukan Identitas Budaya Nasional Dan Promosi Pariwisata Indonesia di Eropa ( Studi
Kasus Diaspora Bali di Perancis ). Jurnal Kepariwisaatan Dan Hospitalitas, 1(2), 180-195.

https://ojs.unud.ac.id/index.php/jkh/artic le/view/35370

Pratama, R. (2021). Imigran dan Warga Keturunan Jepang di Amerika Serikat: Sentimen-Sentimen Terhadapnya Dulu dan Kini. Kiryoku, 5(1), 63-73. https://ejournal.undip.ac.id/index.php/kir yoku/article/view/38019

Pujayanti, A. (2018). Perang Dagang Amerika Serikat-China dan Implikasinya bagi Indonesia. Info Singkat: Bidang Hubungan Internasional, X(07/I/Puslit/April/2018), 7-12. https://berkas.dpr.go.id/puslit/files/info_ singkat/Info Singkat-X-7-I-P3DI-April2018-179.pdf

Sahril A. M., \& Satwikasar, A. F. (2019). Kajian Arsitektur Tradisional Sunda Pada Desain Resort. Purwarupa, 03(4), 65-74.

https://jurnal.umj.ac.id/index.php/purwa rupa/article/view/3991

Santiko, H. (2015). Ragam Hias Ular-Naga di Tempat Sakral Periode Jawa Timur*. Amerta, $33(2), \quad 89$. https://doi.org/10.24832/amt.v33i2.217

Soenjoto, W. P. P. (2019). Eksploitasi Isu Plolitik Identitas Terhadap Identitas Politik Pada Generasi Milenial Indonesia di Era 4.0. Journal of Islamic Studies and Humanities, 4(2), 187-217. https://doi.org/http://dx.doi.org/10.2158 0/jish.42.5223

Sukisman, J. M., Savitri, L., \& Utami, S. (2021). Perlawanan Stigma Warna Kulit terhadap Standar Kecantikan Perempuan Melalui Iklan. Koneksi, 5(1), 67-75. https://doi.org/http://dx.doi.org/10.2491 2/kn.v5i1.10150

Suryana, C. (2018). Makna simbolik dan wujud estetik naga dalam kebudayaan jawa pada sengkalan dwi naga rasa tunggal dan dwi naga rasa wani di 
keraton yogyakarta. $2, \quad 83-91$. https://doi.org/10.34010/artic.2018.2.25 26.83-91

Susilo, A., Rumende, C. M., Pitoyo, C. W., Santoso, W. D., Yulianti, M., Herikurniawan, H., Sinto, R., Singh, G., Nainggolan, L., Nelwan, E. J., Chen, L. K., Widhani, A., Wijaya, E., Wicaksana, B., Maksum, M., Annisa, F., Jasirwan, C. O. M., \& Yunihastuti, E. (2020). Coronavirus Disease 2019: Tinjauan Literatur Terkini. Jurnal Penyakit Dalam Indonesia, $\quad 7(1)$, https://doi.org/10.7454/jpdi.v7i1.415

Thalib, A. A. (2018). Film dan Identitas Nasional Korea Selatan: Studi Komparasi pada Film My Little Hero dan Secretly Greatly. Jurnal Satwika, 2(1), 36.

https://doi.org/10.22219/satwika.vol2.no $1.36-46$

Thalib, A. A. (2019). Isu-Isu Identitas Budaya Nasional dalam Film "Tenggelamnya Kapal Van der Wijck.” Jurnal Satwika, 1(2), 1. https://doi.org/10.22219/satwika.vol1.no 2.1-
Tillman, B. (2011). Creative character design. Elsevier Inc

Trixie, A. A. (2020). Filosofi Motif Batik Sebagai Identitas Bangsa Indonesia. Folio, Vol 1 No 1, 1-9. https://journal.uc.ac.id/index.php/FOLI O/article/view/1380

UNESCO. (2008). Indonesian kris. https://ich.unesco.org/en/RL/indonesiankris-00112

Wright, J. L. (2019). Animation and the Star Body. Film-Philosophy, 194-211. https://doi.org/10.3366/film.2019.0109

Yulianti, I. (2021). Perancangan Desain Karakter Jole Berbasis Lokal Flores, Indonesia. Jags, 7(1), 63-72. https://journal.isi.ac.id/index.php/jags/ar ticle/view/4382/pdf

Yusuf, M. A. (2019). Metode Penelitian: Kuantitatif, Kualitatif dan Penelitian Gabungan (5th ed.). Prenamedia Group. https://books.google.co.id/books?id=Rn ADwAAQBAJ\&printsec $=$ frontcover\&hl $=$ $\mathrm{id} \# \mathrm{v}=$ onepage $\& \mathrm{q} \& \mathrm{f}=$ false 